\title{
DIETARY IRON REQUIREMENT OF THE NILE TILAPIA, OREOCHROMIS NILOTICUS (L.) FINGERLINGS IN INTENSIVE FISH CULTURE
}

\author{
Sabry S. El-Serafy ${ }^{1}$, Magda M. El-Ezabi ${ }^{1}$ \\ Talaat M. Shehata ${ }^{2}$, Neven Esmael ${ }^{2}$ \\ 1- Department of Zoology - Benha University - Faculty of Science, \\ Benha. \\ 2- National Institute of Oceanography and Fisheries, Egypt.
}

Key words: Nile tilapia, Oreochromis niloticus, fish culture, iron, haemoglobin, diet.

\begin{abstract}
The objective of the present study was to determine the dietary iron requirement for the Nile tilapia, Oreochromis niloticus fingerlings in intensive fish culture system. $O$. niloticus fingerlings $(25.36 \pm 0.11 \mathrm{~g})$ were stocked in fiberglass tanks $\left(1 \mathrm{~m}^{3}\right)$ under water running system at a density of $40 \mathrm{fish} / \mathrm{m}^{3}$ with a feeding level of $3 \%$ of body weight. Six purified diets containing different iron levels $(0,200,400,800,1200 \& 1600 \mathrm{mg}$ $\mathrm{Fe} / \mathrm{Kg}$ ) in a form of ferrous sulphate were tested on the Nile tilapia for 8 weeks. Results revealed that FBW and SGR were the highest $(\mathrm{P}<0.05)$ in the fish group fed on the diet supplemented with $1200 \mathrm{mg} \mathrm{Fe} / \mathrm{Kg}$ and the lowest were recorded in fish fed on the iron free diet. Each of $\mathrm{K}$ and FI were insignificantly affected by dietary iron levels. The lowest value of FCR was recorded for fish fed on $1200 \mathrm{mg} \mathrm{Fe} / \mathrm{Kg}$ diet. The results of the present study revealed that, the group of fish fed $1200 \mathrm{mg} \mathrm{Fe} / \mathrm{Kg}$ diet had significantly $(\mathrm{P}<0.05)$ the highest value of average daily gain in weight, PPV and ER. Red blood cell count, haemoglobin and haematocrit values were increased with increasing the level of iron and significantly affected by dietary iron levels. The highest value of $\mathrm{MCH}$ was recorded for fish fed $1200 \mathrm{mg} \mathrm{Fe} / \mathrm{Kg}$ diet. The lowest values of RBCs, Hb, Hct, MCV, $\mathrm{MCH}$ and $\mathrm{MCHC}$ were recorded for fish fed on iron free diet. Total plasma proteins and plasma glucose values were not significantly affected by increasing dietary iron level, while plasma cholesterol increased significantly by increasing the level of iron in the diet. The results of the present study suggest that iron supplemented to the diet up to a level of
\end{abstract}


Sabry S. El-Serafy et al.

$1200 \mathrm{mg} \mathrm{Fe} / \mathrm{Kg}$ diet from ferrous sulphate improves the growth performance and haematological parameters of $O$. niloticus fingerlings.

\section{INTRODUCTION}

Fish reared in intensive recirculation systems have different nutritional requirements from those in the wild. Wild tilapia grazes on blue-green algae and bacteria. The grazing type of feeding requires a lot of energy to search for and to digest the natural food. To meet the energy required for feeding and growth, they must consume more food relative to farm raised fish. In intensive tank culture natural food is not available, therefore, all nutrients must be supplied in a complete pelleted diet. An advantage of feeding a pelleted diet is the higher quality and consistency of the diet ( Rich and Garling, 2003).

Intensification of tilapia culture is a good solution for increasing fish production, and to optimize fish intensification, both feed quality and stocking density should be considered. Addition of artificial feeds plays an important role especially under conditions of heavy stocking when natural feed supply has declined or completely inhibited. The added feeds should be rich in protein, carbohydrate and fats, and should also contain vitamins, minerals and growth-promoting substances to be physiologically balanced (Huisman et al., 1979).

Iron is an essential nutrient for almost all organisms. Iron positioning in the haem moiety of haemoglobin increases oxygen binding and carrying capacity, enabling oxygen transfer to all tissues in multicelluler organisms. One of iron's key cellular functions is to transfer redox activity to the cytochromes involved in respiration (Nicolas et al., 2003).

Iron can change its redox state and can be rapidly oxidized from ferrous to ferric in the presence of oxygen. This reaction generates the superoxide anion, which through a series of redox reactions leads to the generation of toxic hydroxyl radicals (De Silva et al., 1996; Watanabe et al., 1997; Aisen et al., 2001). Thus, iron can be both toxic and beneficial to organisms and its status in the body must be carefully regulated to provide sufficient iron for biological functions, whilst avoiding excess iron which can lead to oxidative stress.

Fish acquire iron predominantly from the diet with negligible iron. uptake from the gills (Andersen, 1997; Bury et al., 2001). In animal tissue, iron is predominantly found in compounds containing a porphyrin nucleus (Coultate, 1996). Oxygen is bound to porphyrin-iron-containing 
molecules either in haemoglobin or in myoglobin. In severe anaemia, iron deficient erythropoiesis may develop and result in reduced haematocrit and blood haemoglobin concentrations. Haematological analysis has commonly been used to detect iron deficiency in fish ( Kawatsu, 1972; Sakamoto \& Yone, 1978; Galtin \& Wilson,1986; Davis \& Galtin, 1991; Andersen et al., 1996; Canli \& Alti,2003; Vangen \&Hemre, 2003 ;ElSaidy\& Gaber, 2004).

The present study is focused on iron requirement of Nile tilapia and its effect on health status of the fish. The concept leads to realize and develop the suiTable iron requirement in an appropriate feed as a complete diet aiming to increase the production of Nile tilapia $O$. niloticus fingerlings reared in closed system.

\section{MATERIALS AND METHODS}

\section{Culture facilities and fish}

The present study was carried out in the aquarium laboratory which belongs to Barrage Fish Farm, ( $30 \mathrm{Km}$ north of Cairo, Egypt), Inland waters and fish culture branch, National Institute of Oceanography and Fisheries. The aquarium laboratory includes six experimental fiberglass tanks $\left(\mathrm{m}^{3}\right)$ with water running system.

A total number of 240 individuals of the freshwater fish $O$.niloticus fingerlings $(25.36 \pm 0.12)$ of both sexes were used in the present experiment. The fish were brought from a private fish farm at Manial Sheha, Giza, Eygpt. Fish were quickly transported to the laboratory and acclimated for environment of the experimental aquarium laboratory for 14 days. Fish were fed on a diet composed of wheat bran, (44\%), soybean meal $(33 \%)$, fish meal $(16 \%)$, corn oil $(5 \%)$ and vitamins as well as mineral salt mixture (2\%). After acclimation, the experiment was carried out for a period that extended to 8 weeks. At the beginning of the experiment, six fiberglass tanks $\left(1 \mathrm{~m}^{3}\right)$ were filled with tap water in a running system, in which 40 fish were stocked in each experimental tank. Aeration was provided through gravity of the running water system in addition to an air pump for each tank. All faeces and pellet residues were removed by siphoning and the water was replaced daily. Six levels of iron (ferrous sulphate heptahydrate) $(0.0,200,400.800,1200$ and $1600 \mathrm{mg} /$ $\mathrm{Kg}$ diet) were tested to determine the average growth performance of O.niloticus under intensive culture using $40 \mathrm{fish} / \mathrm{m}^{3}$ with a feeding level $3 \%$ of total fish biomass. Fish were starved for 48 hours to clear the gut contents before starting the experiment and then fed on the purified diets 
containing different levels of iron three times daily for six days per week and weighed one time every two weeks.

\section{Diet formulation}

The composition of the experimental diet is given in Table (1) and the salt mixture containing six different iron levels is given in Table (2). The diets were formulated using purified casein that was low in iron compared with fish meal as animal protein source. Diets were prepared as dry pellets using California Pellet Meal (CPM) machine by mixing different ingredients mechanically using horizontal mixer. The salts mixtures containing $0,200,400,800,1200 \& 1600 \mathrm{mg} / \mathrm{Kg}$ diet were added at $4 \%$ of dry diet. Different ingredients were mixed then exposed to hot steam to obtain final homogenous pellets.

\section{Growth performance}

Growth performance of Nile tilapia fingerlings were recorded biweekly as described by Bal and Jones (1960), condition factor (K), feed intake (FI) and feed conversion ratio FCR were calculated as reported by Winberg (1960) and Berger\& Halver (1987).

Nutrients utilization parameters (the index of the degree of feed utilization related to growth) includes protein efficiency ratio (PER) (Lie et al., 1988), protein productive value (PPV) and energy retention (ER) were recorded biweekly.

\section{Haematological assay}

At the end of the experiment, fish were sampled from the tanks, 15 fish were randomly taken from each tank for hematological analysis. Careful netting and handling was implemented to minimize stress. Blood was taken using a syringe from the caudal vessel then placed in tubes containing dipotassium ethylendiamine tetra acetic acid (EDTA) as anticoagulant. Red blood cell ( $\mathrm{RBC}$ ), haemoglobin ( $\mathrm{Hb}$ ), haematocrit (HCT), mean corpuscular volume (MCV), mean corpuscular haemoglobin (MCH) and mean corpuscular haemoglobin concentration (MCHC) were determined according to the method described by Agrawal and Mahajan (1983). Blood samples were centrifuged immediately at 4000 r.p.m for 15 minutes for further biochemical analysis. The obtained plasma were frozen until it was used. The plasma was transferred to the laboratory for plasma protein, glucose and cholesterol, determinations according to Agrawal and Mahajan (1983).

Statistical analysis

The obtained data were subjected to statistical evaluation using complete randomized design. The results were analyzed by ANOVA, 
DIETARY IRON REQUIREMENT OF O.NILOTICUS (L.) 169 FINGERLINGS IN INTENSIVE FISH CULTURE

when ANOVA identified significant differences among groups, multiple comparisons among means were made using Duncan's new multiple range test (Duncan, 1955).

\section{Growth performance:}

\section{RESULTS}

Growth performance parameters for tilapia fingerlings fed on, the experimental diets are summarized in Table (3). The results revealed that the values of FBW and SGR of fish fed the diet supplemented with 1200 $\mathrm{mg} \mathrm{Fe} / \mathrm{Kg}$ diet were significantly $(\mathrm{P}<0.05)$ the highest followed by fish fed diets containing $1600,800 \& 400 \mathrm{mg} \mathrm{Fe} / \mathrm{Kg}$ diet and the lowest FBW was recorded with fish fed on iron free diet.

The recorded values of condition factor $(\mathrm{K})$, feed intake (FI) and feed conversion ratio (FCR) were not significantly $(P>0.05)$ affected by increasing dietary iron levels in the diet, However the lowest (best) values of FCR were recorded for fish fed the diet supplemented with $1200 \mathrm{mg}$ $\mathrm{Fe} / \mathrm{Kg}$ diet.

Survival rate of Nile tilapia $O$. niloticus fed on different dietary iron levels was above $92 \%$ for all the treatments, the maximum value $(100 \%)$ of survival rate was achieved by fish fed on diets containing 800 and 1200 $\mathrm{mg} \mathrm{Fe} / \mathrm{kg}$ diet. However, the lowest value $(92.5 \%)$ was recorded with fish fed on iron free diet.

Protein utilization measured as protein efficiency ratio (PER), protein productive value (PPV) and energy retention (ER) as shown in Table (4) were increased by increasing iron level in the diet and reached its highest values with fish fed on $1200 \mathrm{mg} \mathrm{Fe} / \mathrm{Kg}$ diet.

Table (5) shows the values of average daily gain of Nile tilapia, O.niloticus fingerlings (ADG) fed on different dietary iron levels. It is obvious from the data that fish fed $1200 \mathrm{mg} \mathrm{Fe} / \mathrm{kg}$ diet had the maximum $A D G$ value, while fish fed on iron free diet had the lowest value.

\section{Haematological parameters:}

Mean values of red blood cell count, haemoglobin and haematocrit were significantly increased by increasing the levels of iron in the diet (Table 6). The highest values of $\mathrm{RBCs}, \mathrm{Hb}$ and Hct were recorded for fish fed the two iron levels 1600 and $1200 \mathrm{mg} \mathrm{Fe} / \mathrm{Kg}$ diet respectively. The lowest values were recorded for fisin fed on iron free diet.

Dietary iron treatment affected the mean values of $\mathrm{MCV}$ and $\mathrm{MCH}$ and there were significant increases in their values. The highest value of $\mathrm{MCH}$ was recorded for fish fed on $1200 \mathrm{mg} \mathrm{Fe} / \mathrm{Kg}$ diet. On the other 
hand, increasing the level of iron in the diet did not affect $\mathrm{MCHC}$ value and the highest value was recorded for fish fed on $200 \mathrm{mg} \mathrm{Fe} / \mathrm{Kg}$ diet (Table 6).

Total plasma proteins and plasma glucose were not significantly affected by increasing the level of iron in the diet (Table 7). Plasma cholesterol increased significantly by increasing dietary iron and the highest value was recorded for fish fed on $1600 \mathrm{mg} \mathrm{Fe} / \mathrm{Kg}$ diet.

\section{DISCUSSION}

Iron is an essential element for the functioning of organs and tissues of higher animals, including fish, because of its important role in oxygen transport and cellular respiration. Iron is also one of the most important micro nutrients in terms of its effect on immune system functions and host defense against infections (Beisel, 1982; Bhaskaram, 1988). Iron has a number of fundamental roles in cellular biochemistry and metabolism; which include oxygen binding capacity to heme proteins and the formation of active centers in enzymes involved in the mitochondrial electron transport chain (De Silva et al., 1996 ; Aisen et al., 2001).

Results of the present study revealed that fish fed on iron free diet had significantly lower FBW, SGR, survival rate and higher FCR. It showed also the poorest feed utilization values and the poorest average daily gain. Iron supplementation to the diet on the other hand resulted in an improvement in growth performance and feed utilization of the fish. There was a linear increase of these parameters with increasing levels of iron supplementation to the diet up to optimum level of $1200 \mathrm{mg} \mathrm{Fe} / \mathrm{Kg}$ diet. A further increase in iron supplementation does not improve growth performance or feed utilization of the fish.

Based on the obtained results, $O$. niloticus fingerlings stocked under intensive culture of $40 \mathrm{fish} / \mathrm{m}^{3}$ and fed with a feeding level of $3 \%$ of body weight had proved to be the optimum stocking density and feeding level for tilapia fingerlings (Esmael, 2007).

The essentiality of dietary iron for normal growth of Nile tilapia fingerlings under intensive culture was demonstrated by Shiau and Su (2003), that the fish fed on diet supplemented with $150 \mathrm{mg}$ iron/ $\mathrm{Kg}$ diet produced the highest weight gain and the best feed efficiency. An increase in iron concentration did not significantly affect the growth of the fish. Such discrepancy in the amount of dietary iron requirement may be attributed to differences of environmental conditions. 
The effect of iron supplementation to the diet on growth performance of fish has been studied by a number of authors. Lim et al. (1996) and Lim \& Klesius (1997) reported that iron deficiency affects feed conversion ratio of channel catfish, Ictalurus punctatus. Lim et al. (2000) reported also that fish fed iron deficient diets had decreased weight gain, feed conversion and survival. Barros et al. (2002) in their study on the effect of iron supplementation on growth and immune response of channel catfish, Ictalurus punctatus concluded that growth performance of the fish was improved with increasing the level of iron in the diet. They also reported that fish fed on a diet supplemented with $336 \mathrm{mg}$ iron/ $\mathrm{Kg}$ diet produced the highest growth performance of the fish, while fish fed on a diet supplemented with $671 \mathrm{mg}$ iron/ $\mathrm{Kg}$ diet had decreased weight gain, feed intake and FCR.

Fish acquire iron predominantly from the diet. Although fish can absorb soluble iron across the gill membrane and intestinal mucosa (Roeder and Roeadar, 1968), the iron uptake by the gills is negligible as compared with the gut (Andersen, 1997; Bury et al., 2001), and diet is considered the major source of iron for fish due to low concentrations of soluble iron in natural water (NRC, 1993).

In the present study, it is clear that diet is considered the major source of iron for Nile tilapia fingerlings and there is a requirement by tilapia for iron that can not be met by the concentration of iron in the surrounding water. The increase of FBW and SGR are associated with increasing levels of iron in the diet up to optimum level after which they were reduced. The results of the present study are in harmony with the findings of Watanabe et al. (1997), Lim et al. (2000) and Shiau \& Su (2003).

The present study revealed that insignificant increase of condition factor $(K)$ values were detected with increasing dietary iron level. The highest value of $(\mathrm{K})$ was achieved for fish fed on $1200 \mathrm{mg} \mathrm{Fe} / \mathrm{Kg}$ diet supplemented diet. Results concerning the relation between dietary iron levels and condition factor $(\mathrm{K})$ are in accordance with the findings of $\mathrm{El}$ Saidy \& Gaber (2004), who reported that the best values for condition factor $(\mathrm{K})$ were recorded with groups of fish fed on a diet supplemented with $972 \mathrm{mg} \mathrm{Fe} / \mathrm{Kg}$ diet .

Results of the present study showed that values of FCR were not significantly influenced by different dietary iron levels. The lowest (best) value of FCR was obtained for fish fed on $1200 \mathrm{mg} \mathrm{Fe} / \mathrm{Kg}$ diet. In thisconnection, Carriquiriborde et al. (2004) found that there was no effect 
of different dietary iron levels on FCR of rainbow trout, Oncorhynchus mykiss, while Lim et al. (2000) found that FCR was poorest for iron deficient diets but significantly improved when the diets were supplemented with iron.

The lowest values of survival rate were recorded for fish fed on iron free diet and those fed on $1600 \mathrm{mg} \mathrm{Fe} / \mathrm{Kg}$ diet which indicate that both of iron deficiency and the excess of the element could increase the 'mortality rate. This result is in accordance with that obtained by Lim et al. (2000) who reported that the fish fed iron-deficient diets had a decreased survival rate.

Results of average daily gain confirmed that the highest value was recorded for fish fed on $1200 \mathrm{mg} F / \mathrm{Kg}$ diet. This result in addition to results of FBW, SGR K, FCR and survival rate revealed that fish fed the diet supplemented with $1200 \mathrm{mg} \mathrm{Fe} / \mathrm{Kg}$ diet attained the best growth performance and nutrient utilization results.

In the present study, protein efficiency ratio (PER) showed a linear increase (but insignificant) with increasing dietary iron level. On the other hand, Barros et al. (2002) found that PER values of channel catfish, Ictalurus punctatus were significantly increased by increasing dietary iron levels.

Haematological parameters including $\mathrm{Hb}, \mathrm{Ht}, \mathrm{RBC}, \mathrm{MCV} \&$ $\mathrm{MCH}$ were affected by the dietary iron sulphate supplementation. The previous parameters were linearly increased with increasing of dietary iron. MCHC showed an irregular pattern of variation. The highest values of Hb, Hct, RBC, MCV, and MCH were recorded for fish fed on diets containing $\geq 1200 \mathrm{mg} \mathrm{Fe} / \mathrm{kg}$ diet, and lowest values of these parameters were recorded for fish fed on diets containing $\leq 400 \mathrm{mg} \mathrm{Fe} / \mathrm{kg}$ diet.

In the present study, it was noted that the final body weight (FBW), specific growth rate (SGR) and daily weight gain all reached maximum values in fish group fed on $1200 \mathrm{mg} \mathrm{Fe} / \mathrm{kg}$ diet and then declined with a further increase of dietary iron. However, the $\mathrm{Hb}$ concentration, RBC count, Hct and MCV did not decline by a further increase of dietary iron level to $1600 \mathrm{mg} \mathrm{FE} / \mathrm{kg}$ diet. $\mathrm{Hb}$ concentration, $\mathrm{RBC}$ count and $\mathrm{MCV}$ and $\mathrm{MCH}$ and $\mathrm{MCHC}$ showed insignificant differences among treatment of $1200 \mathrm{gm} \mathrm{Fe} / \mathrm{kg}$ diet and treatment of $1600 \mathrm{mg} \mathrm{Fe} / \mathrm{Kg}$ diet. The lack of statistical significance between treatment $1200 \mathrm{mg} \mathrm{Fe} / \mathrm{Kg}$ diet and treatment $1600 \mathrm{mg} \mathrm{Fe} / \mathrm{kg}$ diet indicated that a plateau was reached, when the dietary iron supplementation level was $>1200 \mathrm{mg} / \mathrm{kg}$ diet. 
Results of the present study which showed a linear increase in haematological parameters $(\mathrm{Hb}, \mathrm{RBC})$ with increasing dietary iron levels agree with the findings of Barros et al. (2002). Moreover, EL- Saidy and Gaber (2004) who cleared that $\mathrm{Hct}(\%), \mathrm{Hb}$ and RBCs of Nile tilapia $O$. niloticus were significantly increased with increasing dietary iron levels. However, Carriquiriborde et aL(2004) found no changes in haematological parameters of rainbow trout (Oncorhynchus mykiss) fed on iron deficient, normal and high- iron diets. They added that there was only a small ( but statistically significant) decrease in red cell hemoglobin content in the low Fe fed fish compared with other treatments at the end of the experiment.

In the present, study the groups of fish fed on diets contained < $800 \mathrm{mg} \mathrm{Fe} / \mathrm{kg}$ diet, showed reduced haematological values, the reduction of hematological parameter was severe in fish fed on diets containing < $400 \mathrm{mg} \mathrm{Fe} / \mathrm{kg}$ diet. Fish fed on iron free diet and $200 \mathrm{mg} \mathrm{Fe} / \mathrm{kg}$ diet developed hypochromic microcytic anemia characterized by decreased values of $\mathrm{Hb}, \mathrm{Hct}, \mathrm{MCV}$ and $\mathrm{MCH}$. Vangen and Hemre (2003) reported that during the severe anemia, iron deficient erythropoiesis may develop and result in reduced Hct and blood $\mathrm{Hb}$ concentrations. Iron-deficiency anemia has been observed in brook trout (Kawatsu, 1972), yellowtail (Ikeda et al., 1973), carp (Sakamoto and Yone, 1978) and channel catfish (Gatlin and Wilson, 1986 and Lim et al., 1996). Total cell count (TCC), RBC, Hct and $\mathrm{Hb}$ were significantly lower for fish fed on iron deficient diet (Lim et al., 2000).

In the present study, the mean values of total plasma protein were not significantly influenced by different dietary iron levels, and plasma glucose showed an irregular pattern of variations. These results indicate that there was no clear effect of dietary iron levels on total plasma protein or plasma glucose. Pursuant to this, plasma glucose of juvenile tambaqui Colossoma macropomum showed insignificant differences when fed on different dietary iron leveis (Mastuo et al., 2004)

The present results revealed that the mean values of plasma cholesterol for fish fed on iron levels $\geq 800 \mathrm{mg} \mathrm{Fe} / \mathrm{kg}$ diet showed a significant increase in plasma cholesterol with increasing of dietary iron levels. Similar findings were obtained by Bristow-Craig et al. (1994) and Brunet et al. (1999).

Iron is one of the primary metals involved in lipid oxidation. Ferrous iron, which is more potent than ferric iron, catalyses the formation of hydroperoxides and free radical peroxides by providing a 
free radical initiator in the presence of unsaturated fatty acids and oxygen (Fujimoto et al., 1982).

In conclusion, results of the present study indicate that a supplementation level of $1200 \mathrm{mg} \mathrm{Fe} / \mathrm{Kg}$ diet from ferrous sulphate heptahydrate was sufficient for growth and adequate haematological parameters of $O$. niloticus fingerlings in intensive fish culture.

\section{REFERENCES}

Agrawal, N. K. and Mahajan, C. L. (1983). Hematological and haematopoietic studies in pyridoxine deficient fish, Channa puncutatus Block. J. Fish. Biol., 22: 91 -103.

Aisen, P.; Enns, C. and Wessling-Resnick, M. (2001). Chemistry and biology of eukaryotic iron metabolism. Int. J. Biochem. Cell Biol., 33: 940-959.

Andersen,F.; Maage,A. and Juhshman,K. (1996). An estimation of iron requirement of Atlantic salmon, Salmo salar L., parr. Aquacult. Nutr., 2: 4I- 47.

Andersen, O. (1997). Accumulation of waterborn iron and expression of ferritin and transferrtin in early developmental stages of brown trout, Salmo trutta. Fish Physiol. Biochem., 16:223-231.

Bal, J. N. and Jones, J. W. (1960). On the growth of brown trout of lysine. Tegid. Zool. Soc. Lond., 134:1-41.

Barros, M. M.; Lim, C. and Klesius, P. H. (2002). Effect of soybean meal replacement by cottonseed meal and iron supplementation on growth, immune response and resistance of channel catfish Ictalurus puctatus to Edwardsiella ictaluri challenge. Aquacult., 207: $263-279$.

Beisel, W. R. (1982). Single nutrient and immunity. Am. J. Clin. Nutr., 35:417-468.

Berger, A. and Halver, J. E. (1987). Effect of dietary protein, lipid and carbohydrate content on the growth, feed efficiency and carcass 
DIETARY IRON REQUIREMENT OF O.NILOTICUS (L.) $\quad 175$ FINGERLINGS IN INTENSIVE FISH CULTURE

composition of striped bass Mono sexualities fingerlings. Aquacult., 18: 345-356.

Bhaskaram, P. (1988). Immunology of iron-deficient subjects. In: Chandra, R.K.( ed.) Nutrition and Immunology. Alan, R. Liss, New York, pp. 149-168.

Bristow-Craig, H.E.; Strain, J. J. and Welch, R.W. (1994). Iron status, blood lipids and endogenous antioxidants in response to dietary iron levels in male and female rates. Int. J. Vitam. Nutr. Res., 64: (4) 324-329.

Brunet, S. ; Thibault, L.; Delvin, E.; Yotov, W.; Bendayan, M. and Leavy, E. (1999). Dietary iron overload and induced lipid peroxidation are associated with impaired plasma lipid transport and hepatic sterol metabolism in rats. Hepatology, 29: (6) 1809-1817.

Bury, N. R.; Grosell, M.; Wood, C. M.; Hogstrand, C.; Wilson, R. W.; Rann, J. C.; Busk, M.; Lecklin, T. and Jensen, F.B.(2001). Intestinal iron uptake in the European flounder, Platichthys flesus. J. Exp. Biol., 204:3779-3787.

Canli, M. and Atli, G. (2003). The relationships between heavy metals $(\mathrm{Cd}, \mathrm{Cr}, \mathrm{Cu}, \mathrm{Fe}, \mathrm{Pb}, \mathrm{Zn}$ ) levels and the size of six Mediterranean fish species. Environ. Pollution., pp. 129-136.

Carriquiriborde, P.; Handy, R. D. and Davies, S. J. (2004). Physiological modulation of iron metabolism in rainbow trout, Oncorhynchus mykiss fed low and high iron diets. J. of experimental Biol., 207: 75-86.

Coultate, T. P. (1996). Food The Chemistry of its Components. The Royal Sosiety of Chemistry, Cambridge, UK.

Davis, D. A. and Gatlin, D.M. (1991). Dietary mineral requirements of fish and shrimp. In Proceeding of the Aquaculture Feed Processing and. Nutrition Workshop (ed. D.M. Akiyama and R.K.H.Tan),pp.49-67. Singapore: American Soybean Association. 
De-Silva, D. M.; Askwith, C. C and Kaplan, J. (1996). Molecular mechanisms of iron uptake in eukaryotes. Physiol. Rev., 76: 3147.

Duncan, D. B.(1955). Multiple range and multiple (F) tests. Biometries, 11: $1-42$.

El-Saidy, D. M. and Gaber, M. A.' (2004). Use of cottonseed meal supplemented with iron for detoxification of gossypol as a total replacement of fish meal in Nile tilapia Oreochromis niloticus (L.) diets. Aquacult. Research., 35: 859- 865.

Esmael, N. A. E. F. (2007). Nutritional studies on Nile tilapia, O. niloticus fingerlings in intensive fish culture. M. Sc. Thesis, Faculty of Science, Benha University.

Fujimoto, Y.; Matsui, M. and Fujita, T. (1982). The accumulation of ascorbic acid and iron in rat liver mitochondria after lipid peroxidation. Jpn. J. pharmacol., 32: 397-399.

Gatlin, III, D. M. and Wilson, R. P. (1986).Characterization of iron deficiency and the dietary iron requirement of fingerlings channel catfish. Aquacult., 52: 191- 198.

Huisman , E. J.; Breterler , M. and Vismans , A. (1979). Retention of energy, protein, fat and ash in growing carp Cyprinus carpio under different feeding and temperature regimes. Proceeding World Symposium on Fish Nutrition and Fish.

Ikeda, Y.; Ozaki, H. and Vematsu, K. (1973). Effect of enriched diet with iron in culture of yellow tail. J. Tokyo Univ. Fish., 59: 91-99.

Kawatsu, H. (1972). Studies on the anemia of fish. V. Dietary iron deficient anemia in brook trout, Salvelinus fontinalis. Bull. Freshwater fish. Res. Lab., 22: 59-67.

Lie, O.- Waagbo, R. and Sandnes, K. (1988).Growth and chemical composition of adult Atlantic Salmon Salmo salar fed dry and silas based diets. Aquacult., 69: $343-353$. 
Lim, C.; Sealey, W.M.; Klesius, P. H. (1996). Iron methionine and iron sulfate as sources of dietary iron for channel catfish, Ictalirus punctatus. J. World Aquacult.,Soc., 27: 290-296.

Lim, C. Klesivus, P. H. (1997). Responses of channel catfish(Ictalurus punctatus) fed iron-deficient and replete diets to Edwardsiella ictaluri challenge. Aaquacul., 157: 83-93.

Lim, C.; Klesivus, P. H.; Mengo, H. L. and Robinson, E.H. (2000). Interaction between dietary levels of iron and vitamin $\mathrm{C}$ on growth, hematology, immune response and resistance of channel catfish Ictalurus punctatus to Edwardsiella ictaluri challenge. Aquacult., 185: 313 -327.

Mastuo, A. Y. O.; Roubach, R. and Val, A. L.(2004). Effect of three deferent levels of $\mathrm{Fe}$ ( ferric colret) associated with ascorbic acid (vit. C) in hematology and glucose of juveniles of Tambaqui (Colossoma macropmum). www-heb. pac. dfo-mpo. gc.cal' congress /2004/Culture /18 Arid eEffect.doc.

Nicolas, R. B.; Paul, A. W. and Chris, N. G. (2003). Nutritive metal uptake in teleost fish. J. Experm. Biol. 206: 11-23

National Research Council, NRC (1993).Nutrient requirements of fish. National Academy press, Washington, DC, USA

Rich, M. and Garling, D. (2003). Feeding Tilapia in Intensive Recirculating Systems. Aquaculture Center Fact Sheet Series \#114, August, 2003.

Roeder, M. and Roeader, R. H.(1968). Effect of iron on the growth rate of fishes. J. Nutr., 90: 86-90

Sakamoto, S. and Yone, Y. (1978). Iron deficiency symptoms of carp. Nippon Suisan Gakkaishi, 44: 1157-1160.

Shiau, S.Y. and Su, L.W. (2003). Ferric citrate is half as effectiveas ferrous sulfate in meeting iron requirement of Juvenile tilapia Oreochromis niloticus X O. aureus. J. Nutr., 133 (2): 403- 408. 
Vangen, B. and Hemre, G. I. (2003).Dietary carbohydrate, iron and Zinc interactions in Atlantic salmon Salmo salar. Aquacult, 219:597611.

Watanabe, T.; Kiron, V. and Satoh, S. (1997). Trace minerals in fish nutrition. Aquacult., 151:185- 207.

Winberg, G. G.(1960). Rate of metabolism and food requirement of fish research. Bored. Can., 194: 202. 
DIETARY IRON REQUIREMENT OF O.NILOTICUS (L.) 179 FINGERLINGS IN INTENSIVE FISH CULTURE

Table (1): Diet composition of the experimental diet (purified diet) used to feed Nile tilapia, O.niloticus during the experiment.

\begin{tabular}{|c|c|}
\hline Ingredient & Amount \% \\
\hline Casein (89.0\% protein) & 34.00 \\
\hline Maize Starch & 45.00 \\
\hline$\propto$ - cellulose & 5.00 \\
\hline Corn oil & 10.00 \\
\hline Vitamin mixture & 2.00 \\
\hline Mineral mixture & 4.00 \\
Total & 100 \\
\hline
\end{tabular}

-Vitamins and amiso aciơ mixtures, each $\mathrm{Kg}$ of mixture contained, vit. $\mathrm{A}(10000.000 \mathrm{lU})$, vit. $\mathrm{D}_{3}(1000000$ IU), vit.H(5000 IU), vit. $K_{3}(15000 \mathrm{mg})$, vit. $B_{1}(1500 \mathrm{mg})$, vit. $B_{2}(2000 \mathrm{mg})$, vit. $B_{6}(500 \mathrm{mg})$, vit. $B_{12}$ (1 $\mathrm{mg})$,vit.C(1000 mg ), Niacine(5000 mg), folic acid(100 mg),pantocinic acid(500 mg),Biotine(10 mg)D$\mathrm{L}$ methionine $(14000 \mathrm{mg})$ and $\mathrm{L}$-lysine $(25000 \mathrm{mg})$. The previous mixture was completed with $\propto$ cellulose up to $1 \mathrm{~kg}$. 
Sabry S. El-Serafy et al.

Table (2): The composition of mineral salt mixture used in the six diets during the experiment.

\begin{tabular}{|c|c|c|c|c|c|c|c|}
\hline \multirow{2}{*}{ Minerals } & \multirow{2}{*}{$\mathrm{g} / \mathrm{Kg}$ mixture } & \multicolumn{6}{|c|}{ Iron levels $\mathrm{mg} / \mathrm{Kg}$ diet } \\
\hline & & 0.0 & 200 & 400 & 800 & 1200 & 1600 \\
\hline Calcium orthophosphate & 727.7775 & - & - & - & - & - & - \\
\hline Magnesium sulphate & 127.5000 & - & 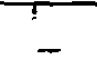 & - & - & - & - \\
\hline Sodium chloride & 60.0000 & - & - & - & - & - & - \\
\hline Potassium chloride & 50.0000 & - & - & - & - & - & - \\
\hline Iron sulphate & * & 0 & 5 & 10 & 20 & 30 & 40 \\
\hline Zinc sulphate & 5.5000 & - & - & - & - & - & - \\
\hline Manganese sulphate & 2.5375 & - & - & - & - & - & - \\
\hline Copper suiphate & 0.7850 & - & - & - & - & - & - \\
\hline Cobalte sulphate & 0.4775 & - & $=$ & - & - & - & - \\
\hline Calcium Iodate & 0.2950 & - & - & - & - & - & - \\
\hline Chromic chloride & 0.1275 & - & - & - & - & - & - \\
\hline
\end{tabular}

* This mixture is completed $101 \mathrm{Kg}$ with $\propto$ - cellulose. This mixture contained $0,5,10,20,30$ and $40.0 \mathrm{~g}$ of iron sulpliate per $\mathrm{Kg}$ of mineral salts mixture,to form six diets containing $0,200,400,800,1200$ and $1600 \mathrm{mg} / \mathrm{Kg}$ of diel, hence the mineral salt mixture was added to the diets at $4 \%$. 
DIETARY IRON REQUIREMENT OF O.NILOTICUS (L.) 181 FINGERLINGS IN INTENSIVE FISH CULTURE

Table (3): Growth performance (mean \pm S.E.) of Nile tilapia, O. niloticus fingerlings as affected with different dietary iron levels.

\begin{tabular}{|l|c|c|c|c|c|c|}
\hline \multirow{2}{*}{ Items } & \multicolumn{5}{|c|}{ Iron level (mg ferrous sulphate $/ \mathrm{kg}$ diet) } \\
\cline { 2 - 7 } & $\begin{array}{c}\text { Iron free } \\
\text { diet }\end{array}$ & 200 & 400 & 800 & 1200 & 1600 \\
\hline Initial body weight (g) & $25.18^{\mathrm{a}}$ & $25.43^{\mathrm{a}}$ & $25.34^{\mathrm{a}}$ & $25.28^{\mathrm{a}}$ & $25.42^{\mathrm{a}}$ & $25.51^{\mathrm{a}}$ \\
$\pm \mathrm{SE}$ & \pm 3.83 & \pm 3.99 & \pm 4.68 & \pm 5.92 & \pm 4.18 & \pm 3.71 \\
\hline Final body weight (g) & $48.58^{\mathrm{c}}$ & $49.43^{\mathrm{c}}$ & $52.34^{\mathrm{b}}$ & $54.53^{\mathrm{b}}$ & $59.22^{\mathrm{a}}$ & $53.12^{\mathrm{b}}$ \\
$\pm \mathrm{SE}$ & \pm 5.18 & \pm 6.04 & \pm 5.39 & \pm 6.86 & \pm 8.24 & \pm 7.61 \\
\hline Specific growth rate & $1.10^{\mathrm{c}}$ & $1.11^{\mathrm{c}}$ & $1.23^{\mathrm{bc}}$ & $1.30^{\mathrm{b}}$ & $1.46^{\mathrm{a}}$ & $1.24^{\mathrm{bc}}$ \\
(\%/ day) \pm SE & \pm 0.29 & \pm 0.34 & \pm 0.39 & \pm 0.42 & \pm 0.32 & \pm 0.43 \\
\hline Condition factor $\pm \mathrm{SE}$ & $1.86^{\mathrm{a}}$ & $1.88^{\mathrm{a}}$ & $1.89^{\mathrm{a}}$ & $1.91^{\mathrm{a}}$ & $1.92^{\mathrm{a}}$ & $1.86^{\mathrm{a}}$ \\
& \pm 0.15 & \pm 0.16 & \pm 0.14 & \pm 0.15 & \pm 0.13 & \pm 0.13 \\
\hline Feed intake (g) $\pm \mathrm{SE}$ & $15.63^{\mathrm{a}}$ & $15.17^{\mathrm{a}}$ & $16.39^{\mathrm{a}}$ & $16.87^{\mathrm{a}}$ & $17.65^{\mathrm{a}}$ & $16.54^{\mathrm{a}}$ \\
& \pm 3.68 & \pm 3.24 & \pm 4.49 & \pm 4.69 & \pm 5.30 & \pm 4.30 \\
\hline Feed conversion ratio & $2.82^{\mathrm{a}}$ & $2.57^{\mathrm{a}}$ & $2.74^{\mathrm{a}}$ & $2.56^{\mathrm{a}}$ & $2.21^{\mathrm{a}}$ & $2.51^{\mathrm{a}}$ \\
$\pm \mathrm{SE}$ & \pm 1.12 & \pm 0.55 & \pm 1.64 & \pm 1.45 & \pm 1.04 & \pm 1.07 \\
\hline Survival rate (\%) & 92.5 & 95 & 97.5 & 100 & 100 & 95 \\
\hline
\end{tabular}

Specific growth rate $=$ Lin final body weight-Lin initial body weight $/$ period (day) $\times 100$

Condition factor $=$ body weigh $/(\text { Body length })^{3} \times 100$, Feed intake $=$ Body weight $x$ feeding level $/ 100$

Feed conversion ratio $=$ feed intake $/$ weight gain $(\mathrm{g}), \mathrm{SE}=$ standard erTor

$a, b, c . . . .$. etc. different superscripts differ significantly $(\mathbb{P}<0.05)$ 
Table (4): Protein efficiency ratio, protein productive value and energy retention (Mean $\pm S$. .) of Nile tilapia, O.niloticus fingerlings as affected with different dietary iron levels.

\begin{tabular}{|l|c|c|c|c|c|c|}
\hline \multirow{2}{*}{ Items } & \multicolumn{5}{|c|}{ Iron level (mg ferrous sulphate $\mathrm{kg}$ diet). } \\
\cline { 2 - 7 } & $\begin{array}{c}\text { Iron free } \\
\text { diet }\end{array}$ & 200 & 400 & 800 & 1200 & 1600 \\
\hline Protein efficiency & $1.32^{\mathrm{a}}$ & $1.33^{\mathrm{a}}$ & $1.48^{\mathrm{a}}$ & $1.58^{\mathrm{a}}$ & $1.75^{\mathrm{a}}$ & $1.49^{\mathrm{a}}$ \\
ratio $\pm \mathrm{SE}$ & \pm 0.51 & \pm 0.29 & \pm 0.62 & \pm 0.73 & \pm 0.75 & \pm 0.58 \\
\hline Protein productive & $23.65^{\mathrm{bc}}$ & $22.53^{\mathrm{c}}$ & $24.71^{\mathrm{bc}}$ & $26.18^{\mathrm{ab}}$ & $28.38^{\mathrm{a}}$ & $23.76^{\mathrm{b}}$ \\
value (\%) $\pm \mathrm{SE}$ & \pm 5.69 & \pm 6.24 & \pm 6.56 & \pm 7.11 & \pm 6.51 & \pm 7.74 \\
\hline Energy retention & $11.85^{\mathrm{b}}$ & $11.78^{\mathrm{b}}$ & $12.55^{\mathrm{b}}$ & $13.30^{\mathrm{ab}}$ & $14.60^{\mathrm{a}}$ & $12.07^{\mathrm{b}}$ \\
$(\%) \pm \mathrm{SE}$ & \pm 3.06 & \pm 3.43 & \pm 3.57 & \pm 3.93 & \pm 3.61 & \pm 4.21 \\
\hline
\end{tabular}

Protein efficiency ratio $=$ Weight gain /protein intake

Protein productive yalue $(\%)=\{$ final body weight $\times(\mathrm{CP} / 100)-$ initial body weight $(\mathrm{CP} / 100) /$ protein intake $\}$ $\times 100$

Energy retention $(\%)=$ (final body weight $\times(G E / 1000)-$ initial body weight $(G E / 1000) /$ energy intake $) \times 100$ $\mathrm{SE}=$ standard cror.

$a, b, c . . .$. etc. different superscripts differ significantly $(P<0.05)$

Table (5): Average daily gain of Nile tilapia, O.niloticus fingerlings as affected with different dietary iron levels.

\begin{tabular}{|l|c|c|c|c|c|c|}
\hline \multirow{2}{*}{ Items } & \multicolumn{5}{|c|}{ Iron level (mg ferrous sulphate /kg diet). } \\
\cline { 2 - 7 } & $\begin{array}{c}\text { Iron free } \\
\text { diet }\end{array}$ & 200 & 400 & 800 & 1200 & 1600 \\
\hline 2 weeks & 0.41 & 0.39 & 0.43 & 0.57 & 0.61 & 0.51 \\
\hline 4 weeks & 0.49 & 0.29 & 0.58 & 0.49 & 0.65 & 0.50 \\
\hline 6 weeks & 0.34 & 0.46 & 0.51 & 0.57 & 0.55 & 0.47 \\
\hline 8 weeks & 0.32 & 0.46 & 0.28 & 0.32 & 0.44 & 0.36 \\
\hline $\begin{array}{l}\text { Mean } \\
\pm \mathrm{SE}\end{array}$ & 0.39 & 0.40 & 0.45 & 0.49 & 0.56 & 0.46 \\
\pm 0.08 & \pm 0.08 & \pm 0.13 & \pm 0.12 & \pm 0.09 & \pm 0.07 \\
\hline
\end{tabular}

$\mathrm{E}=$ standard error, 


\section{DIETARY IROON REQUIREMENT OF O.NILOTICUS (L.) 183 FINGERLINGS IN INTENSIVE FISH CULTURE}

Table (6): Haematological parameters (mean \pm S.E.) of Nile tilapia, O.niloticus fingerlings fed with different iron levels.

\begin{tabular}{|l|c|c|c|c|c|c|}
\hline \multirow{2}{*}{ Items } & \multicolumn{5}{|c|}{ Iron level (mg ferrous sulphate /kg diet) } \\
\cline { 2 - 7 } & $\begin{array}{c}\text { Iron } \\
\text { free diet }\end{array}$ & 200 & 400 & 800 & 1200 & 1600 \\
\hline & & & & & & \\
Haemoglobin (g/dl) $\pm \mathrm{SE}$ & $5.25^{\mathrm{e}}$ & $6.10^{\mathrm{d}}$ & $6.81^{\mathrm{c}}$ & $8.51^{\mathrm{b}}$ & $9.40^{\mathrm{a}}$ & $9.55^{\mathrm{a}}$ \\
& \pm 0.27 & \pm 0.30 & \pm 0.33 & \pm 0.29 & \pm 0.35 & \pm 0.33 \\
Erythrocytic & $1.60^{\mathrm{c}}$ & $1.65^{\mathrm{c}}$ & $1.88^{\mathrm{b}}$ & $2.04^{\mathrm{a}}$ & $2.08^{\mathrm{a}}$ & $2.13^{\mathrm{a}}$ \\
$\left(\times 10^{6} / \mathrm{cmm}\right) \pm \mathrm{SE}$ count & \pm 0.03 & \pm 0.13 & \pm 0.13 & \pm 0.04 & \pm 0.07 & \pm 0.06 \\
Haematocrit (pcv) \% $\pm \mathrm{SE}$ & $21.50^{\mathrm{c}}$ & $22.50^{\mathrm{c}}$ & $27.11^{\mathrm{d}}$ & $31.71^{\mathrm{c}}$ & $35.3^{\mathrm{b}}$ & $38.55^{\mathrm{a}}$ \\
& \pm 1.65 & \pm 1.18 & \pm 2.28 & \pm 2.05 & \pm 1.52 & \pm 1.14 \\
Mean corpuscular volume & $134.45^{\mathrm{d}}$ & $137.03^{\mathrm{d}}$ & $144.11^{\mathrm{cd}}$ & $155.48^{\mathrm{b}}$ & $170.19^{\mathrm{a}}$ & $181.13^{\mathrm{a}}$ \\
(fl) $\pm \mathrm{SE} \mathrm{corpuscular}$ & \pm 11.11 & \pm 12.00 & \pm 17.63 & \pm 10.38 & \pm 10.11 & \pm 8.24 \\
Mean & $32.94^{\mathrm{c}}$ & $37.14^{\mathrm{b}}$ & $36.46^{\mathrm{bc}}$ & $41.74^{\mathrm{a}}$ & $45.25^{\mathrm{a}}$ & $44.87^{\mathrm{a}}$ \\
haemoglobin (Pg) $\pm \mathrm{SE}$ & \pm 1.64 & \pm 3.12 & \pm 4.23 & \pm 1.89 & \pm 2.76 & \pm 2.15 \\
Mean corpuscular & $24.47^{\mathrm{c}}$ & $27.15^{\mathrm{a}}$ & $25.21^{\mathrm{bc}}$ & $26.92^{\mathrm{db}}$ & $25.76^{\mathrm{ab}}$ & $25.57^{\mathrm{ab}}$ \\
haemoglobin concentration & \pm 1.10 & \pm 1.57 & \pm 1.64 & \pm 1.88 & \pm 1.02 & \pm 0.88 \\
(g/dl) $\pm \mathrm{SE}$ & & & & & & \\
\hline
\end{tabular}

SE: stander error

$a, b, c \ldots .$. etc. different superscripts differ significantly $(\mathrm{P}<0.05)$

Table (7): Total plasma protein, plasma glucose and plasma cholesterol (mean \pm S.E.) of Nile tilapia, O.niloticus fingerlings fed with different iron levels.

\begin{tabular}{|c|c|c|c|c|c|c|}
\hline \multirow{2}{*}{ Items } & \multicolumn{6}{|c|}{ Iron level (mg ferrous sulphate $/ \mathrm{kg}$ diet) } \\
\hline & $\begin{array}{c}\text { Iron free } \\
\text { diet }\end{array}$ & 200 & 400 & 800 & 1200 & 1600 \\
\hline $\begin{array}{l}\text { Total proteins } \\
(\mathrm{g} / \mathrm{dl}) \pm \mathrm{SE}\end{array}$ & $\begin{array}{l}4.22^{\prime} \\
\pm 0.37\end{array}$ & $\begin{array}{l}3.90^{\mathrm{a}} \\
\pm 0.36\end{array}$ & $\begin{array}{l}3.90^{2} \\
\pm 0.39\end{array}$ & $\begin{array}{l}4.32^{2} \\
\pm 0.46\end{array}$ & $\begin{array}{l}4.16^{2} \\
\pm 0.45\end{array}$ & $\begin{array}{l}4.10^{2} \\
\pm 0.26\end{array}$ \\
\hline $\begin{array}{l}\text { Glucose }(\mathrm{mg} / \mathrm{dl}) \\
\pm \mathrm{SE}\end{array}$ & $\begin{array}{l}76.00^{b} \\
\pm 2.02\end{array}$ & $\begin{array}{l}88.52^{2} \\
\pm 2.95\end{array}$ & $\begin{array}{l}95.42^{2} \\
\pm 4.59\end{array}$ & $\begin{array}{l}78.68^{b} \\
\pm 5.78\end{array}$ & $\begin{array}{l}75.48^{6} \\
\pm 4.6\end{array}$ & $\begin{array}{l}93.62^{1} \\
\pm 7.75\end{array}$ \\
\hline $\begin{array}{l}\text { Cholesterol } \\
(\mathrm{mg} / \mathrm{dl}) \pm \mathrm{SE}\end{array}$ & $\begin{array}{l}161.62^{\text {d }} \\
\pm 16.28\end{array}$ & $\begin{array}{l}149.18^{8} \\
\pm 11.51\end{array}$ & $\begin{array}{l}165.32^{\text {cd }} \\
\pm 12.91\end{array}$ & $\begin{array}{l}181.12^{c} \\
\pm 19.95\end{array}$ & $\begin{array}{l}260.86^{6} \\
\pm 17.97\end{array}$ & $\begin{array}{l}285.90^{\circ} \\
\pm 14.60\end{array}$ \\
\hline
\end{tabular}

$\mathrm{SE}=$ standard error

$\mathrm{a}, \mathrm{b}$ and $\mathrm{c}$.......etc, different superscripts differ significantly $(\mathrm{P}<0.05)$. 